\title{
AN EXPERIMENTAL ASSESSMENT OF BUSINESS STUDENTS' \\ PERFORMANCE: RECOGNIZING RISK FACTORS ASSOCIATED WITH MISAPPROPRIATION OF ASSETS
}

\author{
Carolyn A. Strand and Kathryn A. S. Lancaster
}

\begin{abstract}
This paper reports the results of a study that was conducted to investigate the performance of senior-level business students as it pertains to recognizing certain clues or risk factors that are frequently associated with the misappropriation of entity assets. Based on three of the risk factors identified in SAS No. 82, an experiment was used to examine differences in performance based on academic major, fraud-specific knowledge, and certain experiences of the students.

The primary contributions of this study are the discovery that: (1) an increasing number of risk factors; (2) knowledge accumulated in an accounting curriculum; (3) reading additional articles on the topic of employee theft; and (4) direct encounters with employee theft in the workplace were positively and significantly associated with recognizing an increased possibility that employee theft may be occurring. The results also indicate that neither employer-provided fraud training, nor part-time
\end{abstract}


work experience, helped the subjects recognize an increased level of vulnerability of an organization to employee theft.

\section{INTRODUCTION}

Many fraud detection experts, public accounting firms, researchers, and managers believe that misappropriation of assets is a growing problem. KPMG, the international accounting firm, has conducted a number of fraud surveys of corporate officials during the $1990 \mathrm{~s}$. In their 1993 study, $96 \%$ of the managers who participated in the survey indicated they were knowledgeable about the ways in which fraud can occur in an organization. That number dropped to $84 \%$ in 1995 and to $80 \%$ in 1998 . Each year, approximately $75 \%$ of the managers indicated that they considered fraud to be a major problem for business and about two-thirds of the respondents believed the incidence of fraud would increase.

The accounting profession is equally concerned about the threat that fraud represents to the business community. The importance of this issue is underscored by Statement on Auditing Standards (SA.S) No. 82, Consideration of Fraud in a Financial Statement Audit (AICPA, 1997). This statement identifies a number of risk factors (sometimes called "red flags" or simply "clues") that are frequently associated with the misappropriation of assets. SAS No. 82 follows recommendations made by the Treadway Commission (1987, p 15) that, "the business and accounting curricula should help students develop stronger analytical, problem solving, and judgment skills to help prevent, detect and deter fraudulent financial reporting ..."

This is atso an important issue due to the magnitude of losses from misappropriation of assets. Calhoun and Luizzo (1992) note that the cost of economic crime in 1990 was at least $\$ 114$ billion, that one dollar is lost to external crime vis-à-vis eight dollars to internal crime, and that one out of three employees is involved in some type of misappropriation of entity assets. Given this widespread concern about employee theft, one might ask how well we are preparing students for this challenging work environment. Can students recognize risk factors that are commonly associated with the misappropriation of entity assets? The purpose of this study is to examine the performance of senior-level accounting students and senior-level management students regarding the identification of clues that could indicate the presence of fraudulent theft of assets within an organization. The current study uses the terms "fraud" and "employee theft" to describe the misappropriation of entity assets.

The remainder of this paper proceeds as follows. The next two sections provide background information on misappropriation of assets and schema 
theory. The following section develops the research hypotheses. We then: provide an overview of the research methodology. Subsequent sections include the results, concluding remarks, and recommendations.

\section{BACKGROUND ON MUSAPPROPRIATION OF ASSETS}

KPMG's annual fraud surveys indicate that the most common type of fraud is misappropriation of assets. Nornan Inkster, President of KPMG Investigation and Security in Toronto, believes that many factors in current business envie ronments - such as downsizing, de-layering, and sophisticated technology - can create opportunities for fraud (Gauthier, 1995). For example, when a company downsizes, layers of management oversight and control are eliminated. This: usually results in more responsibility for fewer managers. In such instances, managers might have more opportunities to override internal eontrols, which would make the detection of misappropriation of assets more difficult.

Seidman (1990) used a survey instrument to gain insights pertaining to more than 500 cases of fraud and was able to develop a profile of a typical perpetrator, a description of commonly used schemes, and a summary of the methods. used by perpetrators to avoid detection. Seidman claims that the outside activ. ities of employees, their lifestyles, and their financial stresses all require careful and continuous scrutiny.

Welch et al. (1996) noted that the internal andit function restricts the ability of perpetrators to access a wide variety of accounts in sustaining a fraud. These authors analyzed 2,573 reported cases involving the misappropriation of assets: in both the public and private sectors, focusing on the victims of the fraud, the characteristics of the perpetrators, the schemes that were used, and the methods of detection. The results indicate that poor company attitudes (control environment) toward existing controls helped the perpetrators commit the fraud. These authors also found that when proper separation of duties was lacking. when employees lacked sufficient competence, or when employees were able to manipulate documentation (internal controls), the probability of employec theft increased significantly. Weak internal controls were often used to the advantage of the perpetrator.

Several researchers and forensic accountants have concluded that purchasing fraud (i.e. fraudulent disbursement of funds) is the most prevalent method employees use to misappropriate assets (Robertson, 1997; Thomhill, 1996: Levy, 1985). Thornhill (1996), a forensic accountant, notes that purchasing fraud fits into the broad category of input tampering, which involves the entry of false or fraudulent data into a computer and can include data that have been altered, forged, or counterfeited. Thornhill (1996) suggests that the persons who 
most often perpetrate a purchasing fraud are trusted, authorized computer users who have either neutralized or avoided any controls that are in place.

It is difficult to detect the misappropriation of assets while the fraudulent activity is in progress. As Albrecht (1996, p. 26) points out, it is not an event that is normally witnessed firsthand. Rather, it is "... a crime shrouded in ambiguity, and is sometimes difficult even to determine whether or not a crime has actually been committed." Too frequently the scheme is discovered by accident. Green and Calderon (1996) believe, however, that "red flags" can create crucial pieces of evidence in signaling the likelihood of employee theft.

Albrecht et al. (1980) conducted an extensive review of existing fraud-related literature to identify the individual and organizational factors (red flags) that might be used to detect employee fraud. Albrecht and Romney (1986) empirically analyzed the predictive ability of the 87 red flags identified in Albrecht et al.'s (1980) study. Results suggest that only about one-third of the red flags were significant predictors of employee theft. Among the red flags that were significant predictors were: (1) failure to require executives to take vacations of more than one or two days at a time; (2) too much trust in key executives (overlooking controls); (3) inadequate internal controls or failure to enforce controls; and (4) poor accounting records. These same red flags were present in the actual instance of misappropriation of assets that was adapted for the present study.

Table 1. Risk Factors Relating to Misappropriation of Assets.*

a. Risk Factors Relating to Susceptibility of Assets to Misappropriation:

- Large amounts of cash on hand

- Inventory characteristics such as small size, high demand, high value

- Easily convertible assets

- Fixed asset characteristics, such as small size, marketability

b. Risk Factors Relating to Controls:

- Lack of hanagement oversight

- No screening procedures for employees with access to vulnerable assets

- Lack of appropriate segregation of duties

- Lack of appropriate authorization and approval of transactions

- Poor physical safeguards over cash, investments, inventory, or fixed assets

- Lack of documentation for transactions

- Lack of mandatory vacations for employees

* Source: Consideration of Fraud in a Financial Statement Audit. Statement on Auditing Standards No. 82. American Institute of Certified Public Accountants (1997). 
SAS 82 provides several examples of red flags (risk factors) believed is the associated with misstatements arising from misappropriation of assets: This statement identifies two categories of risk factors: (a) the general susceptibility of assets to misappropriation, and (b) specific control weaknesses. The initisl category pertains to the nature of an entity's assets and the degree to which they are subject to theft, while the latter pertains to the lack of controls designed: to prevent or detect the misappropriation of assets (AICPA, 1997. para I8) Table 1 provides a list of the two groups of risk factors derived from SAS 82 .

\section{BACKGROUND ON SCHEMA THEORY}

According to Shuell (1986), information processing theories focus on how indi: viduals attend to environmental events; encode information and relate that new: information to knowledge in memory; store new knowledge in memory: and then retrieve and apply that knowledge when it is needed. Under this broud category of theories, psychologists developed schema theory to examine tire idea that much of our knowledge seems to be integrated, that we store tike information together, and that we activate existing knowledge structurif (schemata) to interpret new events (Gagne et al. 1993).

Gagne et al. (1993) note that achieving a schema is a two-step procesi. Fint, a person must construct a schema, and then with instruction and experientes the schema can be developed. Individuals construct a bundle of concepts (a scherny) pertaining to a particular activity and then filter new information fron twe: surrounding environment through that schema when making a decision. For example, a fraud schema is a convenient way to represent a broad frantwort: of fraud information. Then, when a new instance of employee theft is encoune tered, even if it is slightly different from earlier instances, the observer whtt recognize it as having a sufficient number of features in common with the framework that it will also be categorized as fraud. The construction and continued development of a schema in a given area leads to expertise.

Numerous studies in psychology have employed the expert-novice paradigm to study schema theory as it relates to differences in performance. These studier encompass a wide variety of contexts such as chess, electronics, football: writing, and mathematics (Chi et al., 1981, 1982, 1988; Walker, 1987; Mayer, 1982; Larkin et al., 1980; Chi, 1978; Chase and Simon, 1973; de Groot, 1960, 1965). Gagne et al. (1993) note that these researchers typically identify a group of experts and a group of novices, give both groups a problem to solve, then compare the performance of the two groups. By comparing the actions of indlviduals with different levels of expertise in performing different tasks, cognitive 
psychologists are able to identify factors' that account for domain expertise. Alba and Hutchinson (1987) reviewed a number of these psychological studies and found that the results generally supported the idea that increased familiarity with a task leads to increased ability to analyze information and to increased expertise. On the other hand, novices are more likely to oversimplify decisions, to be inefficient in their search strategies, and to ignore the complexities of the decision process.

Accounting researchers began studying expertise in an auditing context in the mid-1970s, using either a behavioral approach or a cognitive approach, to understand professional judgment. The behavioral approach is largely based on Einhorn's (1974) model of the judgment process. Bedard (1989) argues that the behavioral view of expertise ignores the relative differences in the cognitive processes of experts and novices and the way these processes might influence their judgments. The cognitive view of expertise focuses on cognitive processes and the knowledge base underlying the behavior of experts and novices in an attempt to understand how experts make decisions.

After a decade of research in this area, a number of review articles were published (Choo, 1989; Bedard, 1989; Colbert, 1989; Davis \& Solomon, 1989; Bonner \& Pennington, 1991; Bedard \& Chi, 1993; Libby \& Luft, 1993). Choo's (1989) review included the expert-novice research in accounting (auditing) and in psychology. In comparing these two bodies of literature, Choo noted that the accounting and auditing literature is preoccupied with the input, process, and output model, which is in marked contrast to the studies in psychology where the focus is on the underlying difference in experts' versus novices' knowledge structures. Further, Choo (1989, p. 125) suggests that, " . . expertise may be broadly defined as superior schemas (in amount and organization) developed through a gradual process of abstracting domain-specific knowledge on the basis of experience."

Colbert's (1989) review examined the impact of experience on expertise in several auditing tasks. She found that experience may be vital for complex or unstructured decisions, but not necessary for relatively simple or structured judgments\. Bonner and Pennington's (1991) review examined cognitive processes and knowledge as determinants of auditor expertise. Their results suggest that instruction is important for learning and for good task performance. Further, their review suggests a need for more research in several areas of the planning stage of the audit, such as management fraud assessments.

Davis and Solomon (1989) reviewed the accounting literature that examined experience as. a determinant of expertise. These authors are of the opinion that experience can impact the development of expertise in a variety of contexts when the experience facilitates the formation of problem categories. Then, the 
experience can be successfully applied (or transferred) to a variety of situations encountered at a later point in time. Hence, researchers who use experience an expertise surrogate should consider task-specific experience of the accoun: tant rather than tenure.

"Expert" subjects in these auditing studies have variously been defined es audit professionals (Ashton \& Kramer, 1980); individuals with greater years of auditing experience (Tubbs, 1992); those who had experience at or above the level required to complete the task (Colbert, 1989); or audit professionals who had reached the staff level where the required normative skills are developed (Abdolmohammadi \& Wright, 1987). "Novice" subjects were students who had no audit experience, audit professionals with fewer years of auditing experi: ence, individuals who did not have the knowledge to complete the task, or subjects occupying lower staff levels.

While these review articles provide a useful summary of different aspects of this research, several individual studies also focus on a cognitive approach fa explain performance differences in auditing tasks. These studies examine and measure performance (expertise) based on one or a combination of the following factors: knowledge, experience, and ability. For example, Bonner and Lewis (1990) developed four audit tasks to measure the differences in audit expertise of practicing auditors (audit seniors and senior managers) and undergraduate auditing students with no public accounting experience. Based on their results, these authors opine that future research must delineate expertise on the basis of specific training, experience, and ability variables. Tubbs (1992) examined the effect of experience on the auditor's knowledge of errors and inregularities. Tubbs designed two tasks that were completed by auditors in public accounting and students in an introductory auditing class. He found that, consistent with previous audit research, subjects with greater auditing experience recalled more errors, were more accurate about the errors they identified, and recalled more atypical errors.

\section{DEVELOPMENT OF HYPOTHESES}

In the accounting literature, several factors have been studied that are thought to contribute to domain expertise. These include experience (Bonner et al., 1997, Bonner \& Walker, 1994; Libby \& Tan, 1994: Libby, 1993; Tubbs, 1992: Frederick, 1991; Ashton, 1991; Bonner, 1990; Bonner \& Lewis, 1990), knowledge (Bonner et al., 1997; Choo, 1996; Bonner \& Walker, 1994; Libby \& Tan, 1994; Libby \& Luft, 1993; Ashton, 1991; Bonner, 1990; Bonner \& Lewis, 1990), and ability (Bonner \& Walker, 1994; Libby \& Tan, 1994; Libby \& Luft, 1993; Bonner \& Lewis, 1990). These studies use structured tasks to 
cases. They also compare the proposed detection knowledge base with the knowledge base of several experienced auditors. These researchers conclude that one must continually learn new knowledge, and learn how to use what they already know, to successfully detect fraud.

For the purposes of this study, domain-specific knowledge might be obtained from two sources: (1) fraud-specific training, and (2) reading of articles that report the facts and circumstances surrounding actual instances of employee theft which have been uncovered in various entities. Regarding the fraud-specific training, students were asked if they had attended any employer-provided training on the topic of employee theft. Students were also asked whether they had read any articles on the topic of employee theft in local newspapers, the Wall Street Journal, news magazines (such as Newsweek), or similar sources. For those students who responded affirmatively, the next question asked the students to indicate the number of articles they had read in the past 30 days on the topic of employee theft. To test possible performance differences of students based on these two sources of knowledge, we use the following two hypotheses.

H2: When confronted with increasing numbers of fraud risk factors, individuals who have had fraud-specific training will assess the possibility of employee theft at a higher level than will individuals who have not had such training.

H3: When confronted with increasing numbers of fraud risk factors, individuals who read articles on the topic of fraud will assess the possibility of employee theft at a higher level than will individuals who do not read such articles.

\section{Experience}

A number of studies have measured experience by years of work experience or by tenure-based titles (Frederick et al., 1994; Messier, 1983; Chi et al., 1982; Hamilton \& Wright, 1982). Regardless of prior training received, actual work experience should impact the development of schemata. Specifically, the greater the number of years of work experience that individuals gain, the greater the likelihood that they would have developed an awareness of what might be considered "acceptable" in the workplace. Experienced individuals would then be better able to perceive abnormalities. We use the following hypothesis to test possible performance differences between students who have more years of part-time work experience and those who have relatively little work experience. 
H4: When confronted with increasing numbers of fraud risk factors, individuals who have more years of work experience will assess the possibility of employee theft at a higher level than will individuals who have fewer years of work experience.

The second measure of experience examines the impact on schema development $f$ a personal encounter with employee theft in the workplace. According to shton (1991), Larkin et al. (1980), and Elstein et al. (1978), experience must se related to the task since expertise is domain specific. Ashton (1991) investigated the relationship of experience and knowledge as potential determinants of audit expertise and concluded that even the most experienced auditors have limited direct exposure to financial statement errors. As a result, Ashton (1991, p. 219) suggests that "audit experience should be viewed as relating to specific audit tasks rather than as a singular, all encompassing concept and that particular experience must be understood as it relates to a particular type of knowledge."

An actual encounter with employee theft in the workplace and any subsequent retrospection done, in hindsight, as to the weaknesses that lead to it and the warning signals that might have accompanied the incident, can alter any extant schemata. Thus, in the current study, it is hypothesized that such experiences would have an impact on fraud risk assessments. We use the following hypothesis to test possible performance differences between students who have had direct exposure to employee theft in their place of employment and those who have not had this type of experience.

H5: When confronted with increasing numbers of fraud risk factors, individuals who have had experience with employee theft in the workplace will assess the possibility of fraud at a higher level than will individuals who have not had such experience.

\title{
RESEARCH METHODOLOGY
}

\author{
Experimental Design
}

This study employs a $2 \times 2 \times 2$ factorial experiment, utilizing three of the fraud risk factors contained in SAS No. 82. These risk factors are measured at two levels (absent or present). This factorial design requires the formation of eight treatment groups, called scenarios in this study. Each scenario contains a different combination of the three risk factors, and the scenarios were randomly assigned to each participant. A between-subjects design was selected (each student read only one scenario) to overcome demand effects. That is, due to the infrequent nature of fraudulent activity, if each student were to read several 
Table 2. Experiméntal Design.

\begin{tabular}{llllll}
\hline $\mathrm{R}$ & $\mathrm{A} 1$ & $\mathrm{~B} 1$ & $\mathrm{Cl}$ & $\mathrm{EQ}$ & Scenario No. 1 \\
$\mathrm{R}$ & $\mathrm{A} 1$ & $\mathrm{~B} 1$ & $\mathrm{C} 2$ & $\mathrm{EQ}$ & Scenario No. 2 \\
$\mathrm{R}$ & $\mathrm{A} 1$ & $\mathrm{~B} 2$ & $\mathrm{C} 1$ & $\mathrm{EQ}$ & Scenario No. 3 \\
$\mathrm{R}$ & $\mathrm{A} 1$ & $\mathrm{~B} 2$ & $\mathrm{C} 2$ & $\mathrm{EQ}$ & Scenario No. 4 \\
$\mathrm{R}$ & $\mathrm{A} 2$ & $\mathrm{~B} 1$ & $\mathrm{C} 1$ & $\mathrm{EQ}$ & Scenario No. 5 \\
$\mathrm{R}$ & $\mathrm{A} 2$ & $\mathrm{~B} 1$ & $\mathrm{C} 2$ & $\mathrm{EQ}$ & Scenario No. 6 \\
$\mathrm{R}$ & $\mathrm{A} 2$ & $\mathrm{~B} 2$ & $\mathrm{Cl}$ & $\mathrm{EQ}$ & Scenario No. \\
$\mathrm{R}$ & $\mathrm{A} 2$ & $\mathrm{~B} 2$ & $\mathrm{C} 2$ & $\mathrm{EQ}$ & Scenario No. 8 \\
\hline
\end{tabular}

Where: $R=$ Random assignment of the scenarios to the participants

A = Risk Factor No. 1: Lack of appropriate segregation of duties or independent checks

B = Risk Factor No. 2: Lack of timely and appropriate documentation for transactions

C = Risk Factor No. 3: Lack of mandatory vacations for employees performing key control functions

1 = treatment (risk factor) - present

2 = treatment (risk factor) - absent

$E Q=$ Exit quescionnaire that was administered post-test

scenarios - some of which contained more fraud risk factors and others that contained few or no risk factors - the purpose of this research might become transparent to the subject. The experimental design used in the present study is depicted in Table 2.

\section{Subjects}

The subjects who participated in this experiment were traditional-age college students: (1) 237 senior-level management students enrolled in a strategic management course, an organization theory course, or an international management course; and (2) 179 senior-level accounting majors who were enrolled in one of seven different sections of an auditing course. The subjects were from three large state universities in the southwest. Professors motivated the subjects to perform in a serious and conscientious manner by awarding various bonus points. Participation was strictly voluntary. Table 3 identifies the sample of participants for this study.

\section{Task and Procedure}

The case developed for this study draws upon an actual instance where misappropriation of assets occurred as a result of a government employee creating fictitious invoices. Each participant in the experiment read selected background 
Table 3. Sample Identification.

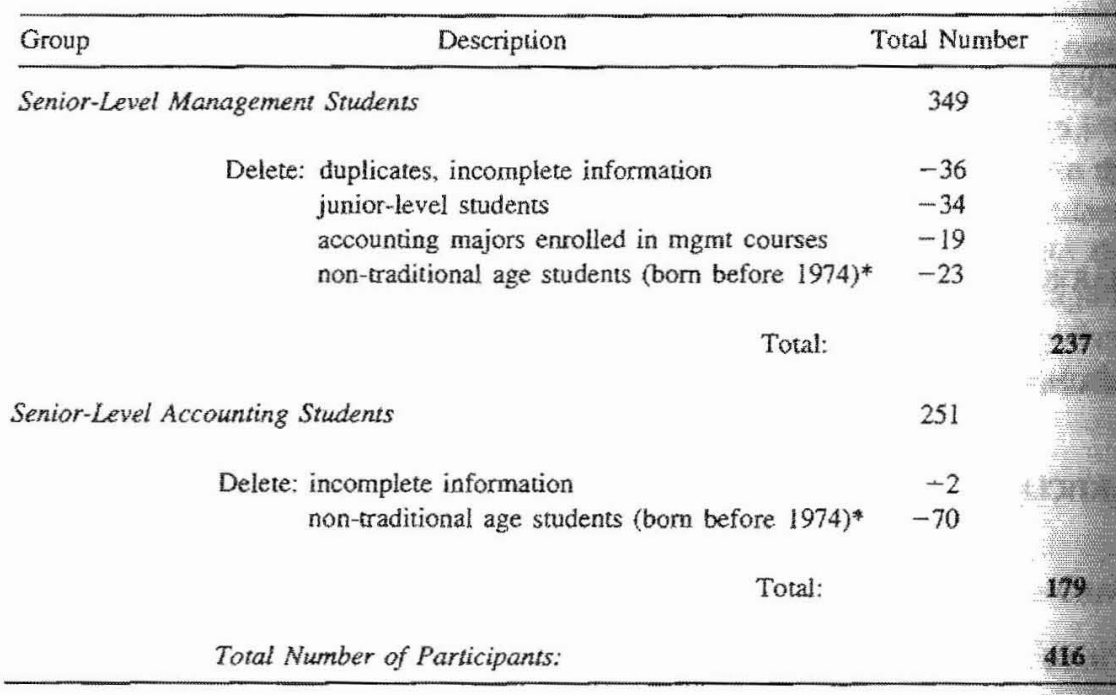

* The purpose of this study is to examine the performance of traditional-age college students retht tive to recognizing risk factors associated with the misappropriation of assets. Therefore, we reducet our sample to include only those students.

information pertaining to the government office being victimized and then considered only one of eight possible scenarios. After reading the case materials, each subject responded to seven questions. Upon completing the experiment, each subject was given an exit questionnaire. This questionaine collected demographic information from the students, contained questions utilized as manipulation checks, and solicited the participant's opinion regarding several aspects of employee theft. Case materials are contained in the Appendix

\section{Variables of Interest}

The dependent variable for this study is the fraud risk assessment that is made by each subject. Each participant was asked to assess the possibility that an employee theft might be occurring. The independent variables were three of the risk factors (RF) from SAS No. 82 that were manipulated at two levels (present or absent): (1) lack of appropriate segregation of duties or independent checks, (2) lack of timely and appropriate documentation for transactions, and (3) lack of mandatory vacations for employees performing key control 
Table 4. Description of Variables.

FRAUD The dependent variable. Subject's assessment of the possibility of fraud, measured as a continuous variable, with a range from 0 to $100 \%$.

RF Number of risk factors contained in the scenario read by the subject, ranged from 0 to 3 .

MAJOR Academic major of the subject. Measured as a dichotomous variable where $1=$ accounting and $0=$ otherwise.

TRAINING Whether or not the subject has obtained any training in the detection of employee theft, measured as a dichotomous variable where $1=$ yes and $0=$ no.

ARTICLES The number of fraud articles the subject has read in the past 30 days, ranged from 0 to 4.

PART Number of years of part-time work experience.

THEFT Whether or not the subject had experienced employee theft at his or her place of employment, measured as a dichotomous variable where $1=$ yes and $0=$ no.

functions. Additional variables, not under the direct control of the researchers, were also utilized in this study. These variables are limited to two categories: knowledge and experience.

In the present study, the knowledge variable is measured in three ways. The initial measure (MAJOR) captures whether or not the subject is pursuing an accounting degree. The second measure (TRAINING) identifies whether or not the subject has had any employer-provided training concerning the detection or prevention of employee theft, and the third measure (ARTICLES) reflects the number of articles the subject has read within the past month on the subject of employee theft. Experience is measured by: (1) the number of years of part-time (PART) work experience that the subject has accumulated, and (2) whether or not the subject has experienced employee theft (THEFT) at his or her place of employment. Table 4 contains a definition of all variables used in this study.

\section{RESULTS AND DISCUSSION}

The results of Chi-square tests indicate that each manipulation check was significant. Standard diagnostic tests were conducted to confirm that the assumptions 
for OLS regression were not violated. The results suggest no major statistical problems.

Descriptive statistics and demographic data are reported in Table 5. The mean age of the accounting students is 21.5 years and the mean age of the management students is 21.8 years. Significantly more management students $(16.9 \%)$ than accounting students $(9.5 \%)$ reported that they had acquired training in the detection of employee theft. However, significantly more accounting students $(73.7 \%)$ reported that they read articles on the topic of fraud than did the management majors $(57.8 \%)$. Senior-level management students reported significantly more years of part-time work experience, and more exposure to theft in the work environment than their accounting peers. The majority of the

Table 5. Descriptive Statistics.

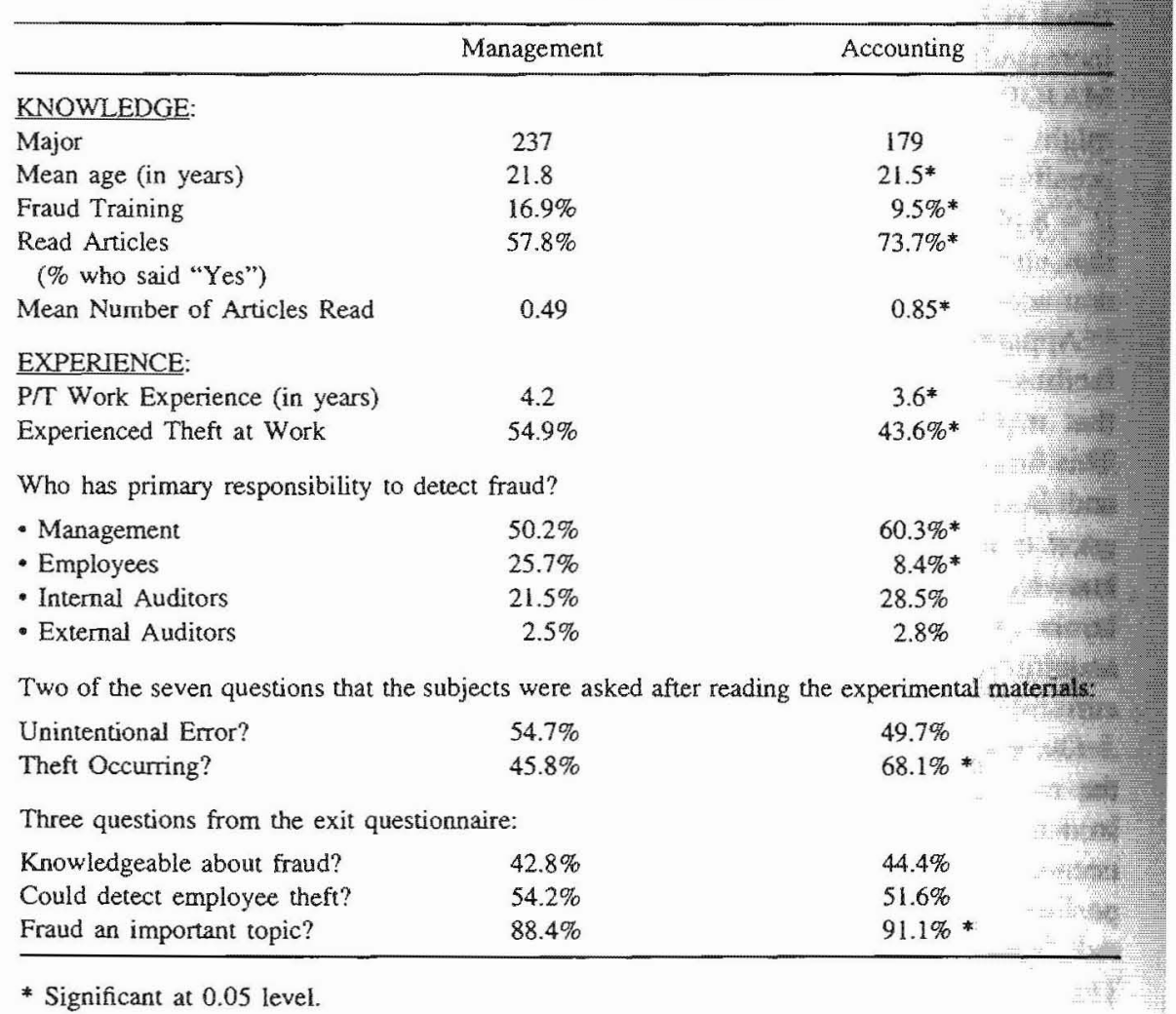


accounting majors $(60.3 \%)$ believed that management has primary responsibility for detecting fraud within an entity. On the other hand, only $50.2 \%$ of the management majors believed that fraud detection was a management responsibility. This difference of opinion between the two groups is significant at the 0.05 level.

Subjects were also asked to assess whether or not misappropriation of assets had occurred in the scenario studied. The accounting majors $(68.1 \%)$ were significantly more apt to believe that employee theft of assets might be occurring than were the management majors $(45.8 \%)$. Finally, while both groups considered the prevention and detection of employee theft an important topic, significantly more accounting majors $(91.1 \%$ ) believed this than did management majors (88.4\%).

Table 6 reports the effects of knowledge on the performance of accounting and management students relative to recognizing the risk factors that might signal employee theft. When they were confronted with increasing numbers of fraud risk factors, both accounting majors and management majors noted an increased possibility that fraud might exist. On average, after controlling for MAJOR, each risk factor added $3.545 \%$ to the subject's assessment that fraud might be occurring. However, accounting majors consistently assessed the possibility of fraud at a higher level than did their non-accounting counterparts $(t=8.695 ; p=0.000)$. Specifically, accounting majors assessed the likelihood that employee theft might be occurring at a full $21.4 \%$ higher level than did non-accounting majors. These results suggest support for Hypothesis One.

Apparently, the unique classroom instruction that accounting majors receive facilitates the identification of potential risks in a business environment that might lead to increased vulnerability to the misappropriation of assets. This finding corroborates similar results found by Bonner and Pennington (1991) and Bonner et al. (1997) that instruction is important for both learning and good task performance. Bonner et al. (1997) found that acquiring some basic knowledge concerning transaction cycle errors prior to actually experiencing errors (the èvent) improved learning. Similarly, accounting majors apparently acquire basic knowledge regarding fraudulent activity from the accounting curriculum.

Our results do not support Hypothesis Two. Regarding fraud-specific training, the results suggest that this type of knowledge is not particularly helpful to students in their assessment of the possibility that employee theft might be occurring. However, reading fraud articles does appear to enhance students' performance in assessing the possibility of employee theft at a higher level as risk factors increase $(t=2.195 ; p=0.029)$, which lends support to Hypothesis Three. 
Table 6. Effects of Knowledge $(n=416)$. $^{*}$

\begin{tabular}{|c|c|c|c|c|}
\hline Variable & $\begin{array}{r}Y_{i}=b_{0}+b_{l} R F \\
\text { Expected } \\
\text { Sign }\end{array}$ & $A A J O R_{i}+b_{3}$ & $G_{i}+b_{4} A R$ & $p-\operatorname{lu}$ \\
\hline Intercept & & 38.751 & 14.330 & 0,000 \\
\hline $\mathrm{RF}$ & $(+)$ & 3.545 & 2.588 & 0,010 \\
\hline MAJOR & $(+)$ & 21.361 & 8.695 & 0.000 \\
\hline TRAINING & $(+)$ & 0.587 & 0.169 & arots \\
\hline ARTICLES & $(+)$ & 3.017 & 2.195 & 0,29 \\
\hline$F$-statistic & $25.116(p=0.0$ & & & \\
\hline Adj. $R^{2}$ & 0.189 & & & \\
\hline where: & \multicolumn{4}{|c|}{$\begin{aligned} \mathrm{Y}_{\mathrm{i}}= & \text { assessment of the possibility of fraud by subject } \mathrm{i} \\
\mathrm{RF}_{\mathrm{i}}= & \text { number of risk factors }(0,1,2 \text {, or } 3) \text { in the Scenario that wat } \\
& \text { randomly assigned to subject } \mathrm{i} \\
\text { MAJOR }_{\mathrm{i}}= & 1 \text { if the subject is an accounting major, and } 0 \text { otherwise } \\
\text { TRAINING }_{\mathrm{i}}= & 1 \text { if the subject has fraud-specific training, and } 0 \text { otherwise } \\
\text { ARTICLES }_{\mathrm{i}}= & \text { the number of fraud articles subject } \mathrm{i} \text { read in the past } 30 \text { days } \\
\varepsilon_{\mathrm{i}}= & \text { error term }\end{aligned}$} \\
\hline
\end{tabular}

* A significant correlation exists between MAJOR and ARTICLES. Therefore, we ran the model: without MAJOR, and then without ARTICLES. Each variable remained statistically significant smd neither coefficient changed significantly. Additionally, the mean age of the management urit: accounting students is significantly different, so to test the effect of age, we included that varitht: in the above model and found no significant changes to the results reported above. Age was nit: found to be a significant variable $(t=0.223 ; p=0.824)$.

These results could be due to a number of factors. First, the type and level of fraud training that the students experienced was most likely focused on employee theft of meals and incidental inventory items due to the fact that the students' part-time employment was generally in restaurants, music stores, and grocery stores. Also, based on their limited exposure to management levels of responsibility, the students' concept of employee theft is probably limited to low-level, observable stealing.

Daniel et al. (1997) claim that the 1990 s most likely will be remembered, among other things, as the decade in which ethics instruction emerged as a vital part of the educational process in training individuals to enter a variety of professions. As a result of this emphasis, perhaps current business students have been required to read a variety of articles that specifically focus on ethical dilemmas that include employee theft. Hence, they might have a better understanding of what would be classified as unethical or illegal behavior. 
The effects of experience on the performance of accounting and management students relative to recognizing the risk factors that might signal employee theft are reported in Table 7. The focus of our study is performance of traditional-age college students, and their work experience was almost entirely part-time employment. Our results suggest that the part-time work experience accumulated by these students did not help them to recognize risk factors. and then to assess the possibility of employee theft at a higher level as risk factors increase.

Apparently, part-time work experience does not provide experience that might improve an individual's performance in detecting or recognizing the clues that are commonly associated with employee theft. Perhaps this variable should be tested on those with full-time work experience. Such experience implies that the employees are in the work environment more hours each week, which might be essential for accumulating and assimilating clues from the environment (more

Table 7. Effects of Experience $(n=416)$.*

\begin{tabular}{|c|c|c|c|c|}
\hline \multirow[b]{2}{*}{ Variable } & \multicolumn{4}{|c|}{$Y_{i}=b_{o}+b_{1} R F_{i}+b_{2} M_{A J O R_{i}}+b_{3} P_{A R T_{i}}+b_{4} T_{H E F T_{i}}+\varepsilon i$} \\
\hline & Expected Sign & Coefficient & $t$-statistic & $p$-value \\
\hline Intercept & & 38.646 & 10.787 & 0.000 \\
\hline RF & $(+)$ & 3.755 & 2.751 & 0.006 \\
\hline MAJOR & $(t)$ & 22.797 & 9.424 & 0.000 \\
\hline PART & $(t)$ & -0.362 & -0.648 & 0.517 \\
\hline THEFT & $(+)$ & 5.244 & 2.154 & 0.032 \\
\hline$F$-statistic & \multicolumn{4}{|l|}{$25.028(p=0.000)$} \\
\hline Adj. $R^{2}$ & \multicolumn{4}{|l|}{0.188} \\
\hline where: & \multicolumn{4}{|c|}{$\begin{aligned} \mathrm{Y}_{\mathrm{i}}= & \text { assessment of the possibility of fraud by subject } \mathrm{i} \\
\mathrm{RF}_{\mathrm{i}}= & \text { number of risk factors }(0,1,2 \text {, or } 3) \text { in the Scenario that was } \\
& \text { randomiy assigned to subject } \mathrm{i} \\
\text { MAJOR }_{\mathrm{i}}= & 1 \text { if the subject is an accounting major, and } 0 \text { otherwise } \\
\text { PART }_{\mathrm{i}}= & \text { years of part-time work experience } \\
\text { THEFT }_{\mathrm{i}}= & 1 \text { if the subject has had experience with employee theft at his or her } \\
& \text { place of employment, and } 0 \text { otherwise } \\
\varepsilon_{\mathrm{i}}= & \text { error term }\end{aligned}$} \\
\hline
\end{tabular}

* A significant correlation exists between PART and THEFT. Therefore, we ran the model without PART, and then without THEFT. PART remained statistically insignificant and THEFT remained statistically significant. Further, neither coefficient changed significantly. We performed an additional sensitivity test by examining PART as a dichotomous variable where $1=$ five or more years of work experience, and 0 otherwise. THEFT remained statistically significant. 
exposure to potential wrong doing). Also, working at a higher level in the orgat nization offers a wider perspective of the operations of the entity. Nevertheless, based on our results, we find no support for Hypothesis Four.

On the other hand, prior experience with employee theft does appear to sen: sitize both accounting and management majors to the increased possibility of employee theft $(t=2.154 ; p=0.032)$. This result, which is both interesting and important, suggests that those who have dealt with fraudulent employee active ties in the past would be more likely to detect abnormalities in their work envi: ronment and would assess the possibility of employee theft at a higher level then those who have not had such experience. Perhaps individuals who have person: ally encountered employee theft in a past work environment have included the information gained from this experience in their existing schemata for misap: propriation of assets. These results suggest support for Hypothesis Five.

In our final analysis, we consider a single regression equation that includes: the three risk factors, the three knowledge variables, and the two experience

Table 8. Effects of Knowledge and Experience $(n=416)$

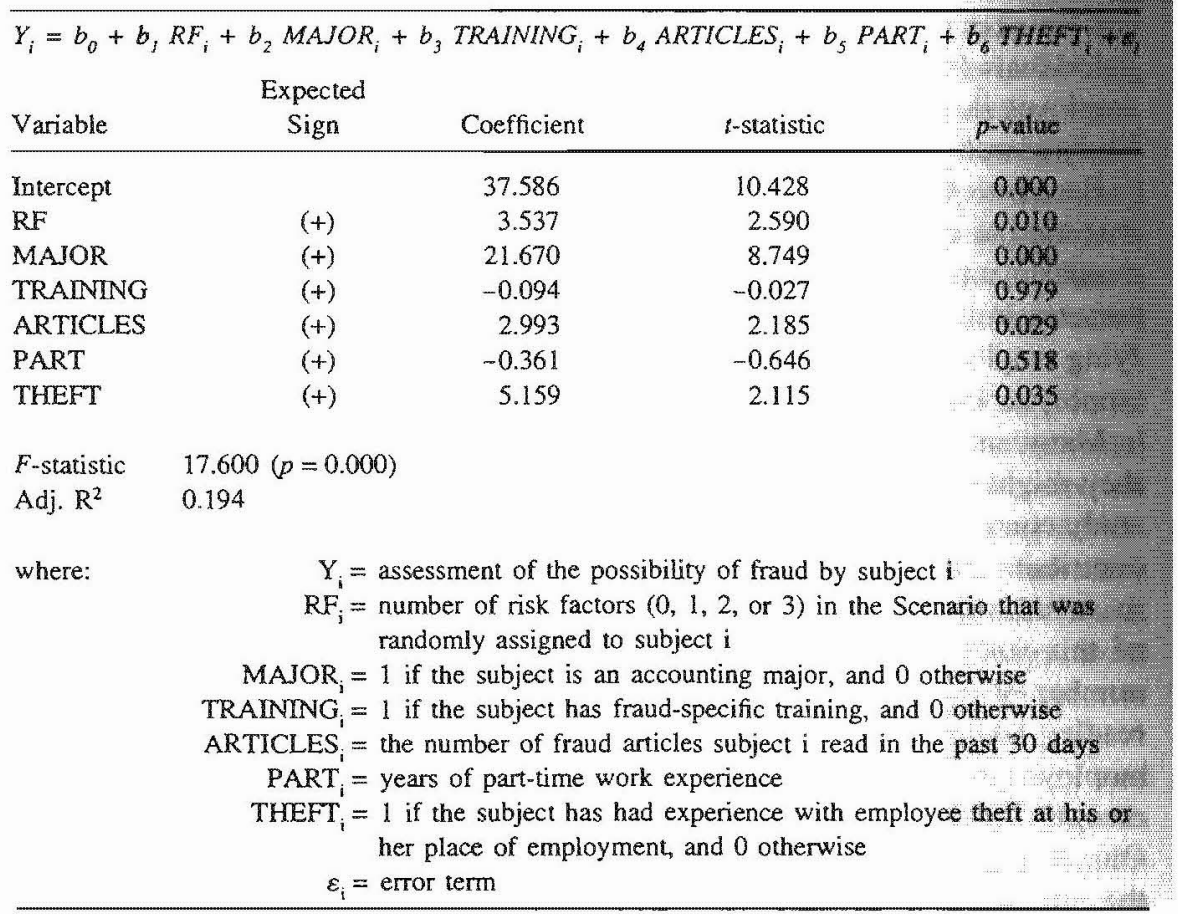


variables. We report the results of this analysis in Table 8 . The risk factors are still significant $(t=2.590 ; p=0.010)$. The two knowledge variables that were significant in our earlier test remain significant: the student's academic major $(t=8.749 ; p=0.000)$ and reading fraud articles $(t=2.185 ; p=0.029)$. Finally, the student's exposure to employee stealing in the workplace $(t=2.115$; $p=0.035$ ) remained a significant variable in helping students recognize the potential vulnerability of the organization when risk factors are present. Thus, the results we obtained by combining the knowledge and experience variables into one regression are consistent with the results we found when looking separately at the knowledge variables, and then the experience variables.

\section{CONCLUSIONS AND RECOMMENDATIONS}

Albrecht (1996) maintains that fraud is sometimes so ambiguous that it is difficult even to know whether or not a crime has occurred, and fraud indicators can be present even when fraud does not exist. He notes that, when employee theft is in progress, only the symptoms exist and many of them go unnoticed. Both Ashton (1991) and Loebbecke et al. (1989) contend that fraud detection is difficult because, by its very nature, a fraudulent act is covertly accomplished and most individuals have very little direct experience with detecting and investigating employee theft. With such limited exposure, the presence of risk factors is most likely essential, if not critical, to detection of employee theft within an entity.

Based on three of the risk factors identified in SAS No. 82, an experiment was used to examine the differences in performance of accounting students and management students relative to recognizing these specific risk factors. Our concern is whether they are prepared to meet the specific challenge of identifying employee theft by recognizing the clues that are frequently available when employee wrong doing is in progress.

Many studies have examined knowledge and experience to determine how they might be associated with performance (expertise) in a particular area. This study contributes to that body of literature by identifying which of these factors contribute to expertise in an unstructured task - that of detecting clues common to an instance of misappropriation of entity assets. The primary contributions of this study are the discovery that, for business students: (1) an increasing number of risk factors; (2) the requirements of an accounting curriculum; (3) reading additional articles on the topic of fraud; and (4) direct encounters with employee theft in the workplace are positively and significantly associated with recognizing an increased possibility that employee theft might be occurring. Our results also indicate that employer-provided fraud training obtained by the students was not particularly useful, and an individual's part-time work 
experience was not found to be associated with a greater awareness of the possibility of misappropriation of assets when risk factors were present.

The annual fraud surveys conducted by KPMG continue to document the: fact that employee misconduct is a growing concern to the business community, which implies that the topic is relevant for classroom instruction if business school graduates are to be properly prepared for the work environment Although fraud-specific training was not a significant variable, direct expostre to theft in the workplace was significant. We believe academicians, accounting: practitioners, and those in business would agree that the preferred method for preparing students to recognize employee theft is classroom instruction and training, not random exposure to employee theft in the workplace.

Specifically, the content and delivery of current fraud training programs may be improved by focusing on actual instances of employee theft so that students might gain the maximum amount of benefit from the instruction. This may be accomplished through a combination of case studies (e.g. Dwyer, 1998; Peterson and Gibson, 1999) and training videos that explain a variety of actual instances. of fraud - the perpetrator, the scheme that was used, how the fraud was detected, and other particulars. Such training might prove to be a useful surrogate for actual experience with employee theft. Bonner's (1990) results indicate that task-specific knowledge aided experienced auditors in making better decisions which suggests focused training and decision aids should improve performance:

Recent studies offer specific suggestions for improved learning from instrue: tion. Bonner and Walker (1994) found that instruction with no experience, and instruction with no feedback, do not produce knowledge. In contrast, subjects gain knowledge when they practice and receive explanatory feedback. Choo's (1996) results indicate that prolonged practice or exposure to the event promotes expertise.

The timing of this instruction also appears to be important. Based on Bonner et al.'s (1997) study, instruction prior to experiencing an event is instrumental to improved learning. These authors investigated the effect of instruction on judgment and decisions by varying the timing of the instruction. Using undergraduate accounting and MBA students, the authors examined whether intensive instruction helped the students apply that knowledge to later audit decisions, Results indicate that instruction facilitated the acquisition of knowledge about transaction cycle errors, and that having this basic category knowledge prior to experiencing errors improved learning.

Overall, the results obtained in our study of senior-level accounting and management majors present an opportunity for each business school to assess its curriculum as it relates to misappropriation of assets and incorporate fraud training into appropriate courses of instruction. More targeted classroom instruction 
on the topic of employee theft might provide better preparation for the business environment than chance encounters with a real-life instance of employee theft in the workplace.

Studies of this type have a number of limitations. One such limitation is the choice of subjects that were used in the experiment. The students came from three large universities that have rather diverse student bodies, and should be representative of those population groups. Nevertheless, these universities were all located in the same state and may not be representative of students in other geographical areas. Another limitation might be the experimental case that was used for this research. Since the case relates to a government office, the information could be sufficiently unfamiliar to some students that it may have caused confusion. Finally, due to the large number of subjects required for this study, the experiment was conducted over a three-week period at one of the universities. Thus, students in one class might have shared information with students in other classes. To the extent possible, this problem was mitigated by scheduling the experiments for each course as closely together as possible.

\section{ACKNOWLEDGMENTS}

The authors gratefully acknowledge the research assistance of Beth Oppenlander, an MBA student at Seatte Pacific University. We are also indebted to anonymous reviewers, the associate editor, and the editor for their insightful comments and suggestions.

\section{REFERENCES}

Abdolmohammadi, M., \& Wright, A. (1987, January). An examination of the effects of experience and task complexity on audit judgments. The Accounting Review, 1-13.

Alba, J., \& Hutchinson, J. (1987, March). Dimensions of consumer expertise. Journal of Consumer Research, $411-454$.

Albrecht, W. (1996, October). Employee fraud. The Internal Auditor, 26-37.

Albrecht, W., \& Romney, M. (1986). Red-flagging management fraud: A validation. Advances in Accounting, 3, 323-334.

Albrecht, W., Charrington, D., Payne, I., Roe, A., \& Romney, M. (1980). Auditor involvement in the detection of fraud. In: R. Ellion \& J. Willingham (Eds), Management Fraud: Detection and Deterrence. New York, NY: Petrocelli Books, lnc.

American Institute of Certified Public Accountants. (1997). Consideration of fraud in a financial statement audit. Statement on Auditing Standards No. 82. New York, NY: AICPA.

Ashton, A. (1991, April). Experience and error frequency knowledge as potential deterninants of audit experise. The Accotanting Review, 218-239.

Ashton, A., \& Kramer, S. (1980, Spring). Students as surrogates in behavioral accounting research: Some evidence. Journal of Accounting Research, 1-15. 
Bedard, J. (1989,). Expertise in auditing: Myth or reality? Accounting, Organizations, and Sactery $1 / 2,113-131$.

Bedard, J., \& Chi, M. (1993, Supplement). Experise in auditing. Auditing: A Journat of Practce \& Theory, 22-45.

Bonner, S. (1990, January). Experience effects in auditing: The role of task-specific knowledge. The Accounting Review, 72-92.

Bonner, S., Libby, R., \& Nelson, M. (1997). Audit category knowledge as a precondition to learninis from experience. Accounting, Organizations, and Society, 5, 387-410.

Bonner, S., \& Walker, P. (1994, January). The effects of instruction and experience on the acquit: sition of auditing knowledge. The Accounting Review, 157-178.

Bonner, S., \& Pennington, N. (1991), Cognitive processes and knowledge as determinants of zuditits expertise. Joumal of Accounting Literature, 10, 1-50.

Bonner, S., \& Lewis, B. (1990, Supplement). Determinants of auditor expertise Journat af Accounting Research, 1-28.

Calhoun, C., \& Luizzo, A. (1992, October). Team partners in fraud detection. The CPA Youmet. 32-36.

Chase, W., \& Simon, H. (1973). Perception in chess. Cognitive Psychology, 4, 55-81.

Chi, M. (1978). Knowledge structure and memory development. In: R. S. Siegler (Ed.), Childrent: Thinking: What Develops? Hillsdale, NJ: Lawrence Erlbaum Associates.

Chi, M., Glaser, R., \& Farr, M. (1988). The Nature of expertise. Hillsdale, NJ: Lawrence Erbaum Associates.

Chi, M., Glaser, R., \& Rees, E. (1982). Expertise in problem solving. Advances in the Psycholosy of Human Intelligence, 1, 7-75.

Chi, M., Feltovich, P., \& Glaser, R. (1981). Categorization and representation of physics problett: by experts and novices. Cognitive Science, 5, 121-152.

Choo, F. (1996). Auditors' knowledge content and judgment performance: A cognitive seript. approach. Accounting, Organizations, and Society, 4, 339-359.

Choo, F. (1989). Expert-novice differences in judgment/decision making research Joumal of Accounting Literature, 8, 106-136.

Colbert, J. (1989). The effect of experience on auditors' judgments. Joumal of Accounting: Literature, 8, 137-149.

Daniel, L., Elliott-Howard, F., \& DuFrene, D. (1997). The ethical issues rating scale: An instru: ment for measuring ethical orientation of college students toward various business practices. Educational and Psychological Measurement, 3, 515-526.

Davis, J., \& Solomon, I. (1989). Experience, expertise, and expert-performance research in public accounting. Joumal of Accounting Literature, 8, 150-164.

De Groot, A. (1966). Problem solving. New York, NY: Wiley.

De Groot, A. (1965). Thought and choice in chess. The Hague, Netherlands: Mouton.

Dwyer, P. (1998, November). Embezzlement at the University of Califomia: An instructional case in employee fraud. Issues in Accounting Education, 975-984.

Einhorn, H. (1974). Expert judgment: Some necessary conditions and an example. Joumal of Applied Psychology, 562-571.

Elstein, A., Shulman, S., \& Sprafka, S. (1978). Medical problem solving: An analysis of clinical reasoning. Cambridge, MA: Harvard University Press.

Frederick, D. (1991, April). Auditors' representation and retrieval of internal control knowledge. The Accounting Review, 240-258.

Frederick, D., Heiman-Hoffman, V., \& Libby, R. (1994). The structure of auditors' knowledge of financial statement errors. Auditing: A Journal of Practice \& Theory, 1, 1-21. 
Gagne, E., Yekovich, C., \& Yekovich, F. (1993). The cognitive psychology of school learning. New York, NY: Harper Collins College Publishers.

Gauthier, Y. (1995, October). Forever fraud. Internal Auditor, 26-29.

Green, B., \& Calderon, T. (1996). Information privity and the internal auditor's assessment of fraud risk factors. Internal Auditing, 4, 4-15.

Hamilton, R., \& Wright, W. (1982, Autumn). Internal control judgments and effects of experience: Replications and extensions. Journal of Accounting Research, 756-765.

Johnson, P., Grazioli, S., \& Jamal, K. (1993). Fraud detection: Intentionality and deception in cognition. Accounting, Organizations, and Society, 5, 46,7-488.

KPMG. (1998, 1995, 1994, 1993). Fraud Survey Results. New York, NY: KPMG.

Larkin, J., McDermott, J., Simon, D., \& Simon, H. (1980, June). Expen and novice performance in solving physics problems. Science, $1335-1342$.

Leatherwood, M., \& Spector, L. (1991). Enforcements, inducements, expected utility and employee misconduct. Journal of Management, 3, 553-569.

Levy, M. (1985, August). Financial fraud: Schemes and indicia. Journal of Accountancy, 78-87.

Libby, R. (1993). The role of knowledge and memory in audit judgment. In: R. Ashton \& A. Ashton (Eds), Judgment and Decision Making Research in Accounting and Auditing. Cambridge, MA: Cambridge University Press.

Libby, R., \& Tan, H. (1994). Modeling the determinants of andit expertise. Accounting. Organizations, and Society, 8, 701-716.

Libby, R., \& Luft, J. (1993). Determinants of judgment performance in accounting settings: Ability, knowledge, motivation, and environment. Accounting, Organizations, and Society, 5, $425-450$.

Loebbecke, J., Eining, M., \& Willingham, J. (1989). Auditors' experience with material irregularities: Frequency, nature, and detectability. Auditing: A Journal of Proctice \& Theory, 1-28.

Mayer, R. (1982). Memory for algebra story problems. Joumal of Educational Psychology, 199-210.

Messier, W. (1983, Autumn). The effect of experience and firm type on materiality disclosure judgments. Journal of Accounting Research, 611-18.

Peterson, B., \& Gibson, T. (1999, February). Fraud detection and investigation: Microcomputer consulting services. Issues in Accounting Education, 99-115.

Robertson, J. (1997). Fraud examination for managers and auditors. Austin, TX: Viesca Books.

Shuell, T. (1986, Winter). Cognitive conceptions of learning. Review of Educational Research, 411-436.

Seidman, J. (1990, January). A case study of employee fraud (reprint of 1939 article). The CPA Joumal, 28-35.

Thornhill, W. (1996, Summer). Input tampering. Internal Auditing, 46-50.

Treadway Commission. (1987). Report of the National Commission on Fraudulent Financial Reporting. Washington, DC: National Commission on Fraudulent Financial Reporting.

Tubbs, R. (1992, October). The effect of experience on the auditor's organization and amount of knowledge. The Accounting Review, 783-801.

Walker, C. (1987). Relative importance of domain knowledge and overall aptitude on acquisition of domain-related information. Cognition and Instruction, 25-42.

Welch, S., Holmes, S., \& Strawser, R. (1996, Fall). The inhibiting effect of internal auditors on fraud. Internal Auditing, 23-32. 


\section{APPENDIX}

CASE MATERIALS

Background Information

Stan Stevens was pleased. He recently accepted the position of Finance Director of Lonely Star, a city in the U.S. with a population just over 60,000 . The cily? has been growing steadily over the past several decades, and collected over $\$ 80$ million in gross operating revenues during the last fiscal year.

Stan's picture has already appeared on the front page of the business section of the local newspaper. In the interview for that feature article, Stan shared his: vision for the future of the Finance Department and identified a number of: long-term goals he hoped to achieve. However, Stan noted that initially he: planned to focus his attention and efforts on a variety of day-to-day concerns: he had about the department.

First, he plans to streamline procedures in the department by eliminating certain accounts that are rarely used. He also wants to improve the efficiency of his department, so that information can be provided quickly when reeded by citizens or other city agencies, thus increasing outsiders' confidence in the department. Stan is particularly keen about addressing the problem of employee turnover. Five of the seven employees in the department have been with the city for less than a year. Stan has been told that the prior Finance Director was: very controlling and task-oriented, and that this may have caused department staff to seek employment elsewhere.

Stan noted that the city does not have an internal audit staff, but the local: accounting firm of Watson \& Watson, CPAs has been the Independent Auditor of the City's Comprehensive Annual Financial Report for more than a decade. In addition to Stan, the Finance Department includes the following personnel:

1. Linda North, Chief Accountant. Manages and maintains the General Ledger. Linda is also responsible for general office management and day-to-day operations in the department. Employed by the department for 15 years, Linda is 37. Linda's husband owns a janitorial cleaning service in town and she does all the bookkeeping for her husband's business.

2. Mary West, Senior Accountant. Responsible for monitoring fixed assets. She also maintains all records of city fixed/real assets and maintains/monitors all city construction and acquisition of real asset contracts. Employed by the department for 8 months, Mary is 39. Mary's husband is employed by the U.S. Post Office. 
3. Wesley Joines, Staff Accountant. Cash Mánager, and also maintains bank relations, monitors all city investments and debt service requirements, and performs all wire transfers of city funds. Employed by the department for 7 months, Wesley is 32 . His wife is a local beautician.

4. Cynthia Clark, Staff Accountant. Maintains all records pertaining to Accounts Receivable, invoices those who owe funds, maintains control of all Petty Cash Funds within the city, accounts for all daily deposits from departments and divisions within the city, and is also the secondary payroll clerk. Employed by the department for almost 9 months, Cynthia is 38 and her husband is a math teacher at the High School.

5. Robert Thomas, Accounts Payable Clerk. Processes all city payments to payees for last names beginning with $\mathrm{A}$ through $\mathrm{L}$. Employed by the department for 20 months, Robert is 36 , single, and has lived in lown his whole life except for the 4 years he served in the U.S. Navy.

6. Nancy Martin, Accounts Payable Clerk. Processes all city payments to payees for last names beginning with $M$ through $Z$. Employed by the department for 6 months, Nancy is 26 and a single parent. She lives in a near-by town.

7. Chase Schultz, Payroll Clerk. Processes all bi-weekly and monthly payrolls and maintains all payroll records. Chase is 31 , recently divorced, and has been employed by the department for 10 months. He lives in an older neighborhood of the city. 
Organizational Chart

Finance Department of Lonely Star.

Stan Stevens

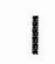

Linda North

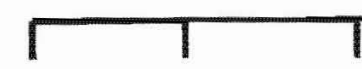

Mary
West

Wesley
Joines

Cynthia
Clark

Robert
Thomas

Nancy Martin

Risk Factors: Present

A1: Over the past four months, Stan has asked Linda several times to develop controls over the accounts payable function for the City. The prior Finance Director had abolished these controls because she thought they were unnecessary. However, Stan knows they are important, so he wants two checks: (1) each accounts payable clerk (Nancy and Robert) to check the other's work, and (2) the senior accountant (Mary) to check the work of both of the accounts payable clerks. The controls have just recently been implemented, and Linda has complained repeatedly about how slowly Mary performs this task. Linda says that Mary is holding up the payments 10 suppliers, so Linda has volunteered to check Nancy's and Robert's work this week to see how long it would take her to do it.

B1: Each Tuesday evening, the City runs checks for the invoices that are due that week. Then, on Wednesday moming, the accounts payable clerks verify the amount of each check with the register and also confirm that all 
supporting documents are attached. After Mary reviews the registers and documentation, the checks are mailed out to the vendors. Mary is concerned. She is reviewing Nancy's and Robert's work and Mary cannot locate the supporting documents for a $\$ 10,000$ check on Robert's check register. The check appears to be missing also.

$\mathrm{Cl}$ : Robert and Linda are the only employees who have been with the department long enough to accrue any vacation time. Robert just returned from a four-day vacation hiking in the Big Bend area. Linda has not taken any vacation for the past two years. She maintains this is necessary because there are so many new employees. Linda does appear to be busy. She is consistently the first to arrive at work each day and the last to leave at night. However, Linda is at the point where she will lose a lot of vacation days, so Stan has insisted that she take vacation. Linda agreed to do this, but takes only one day at a time.

Risk Factors: Absent

A2: Four months ago, Stan asked Linda to develop controls over the accounts payable function for the City. The prior Finance Director had abolished these controls because she thought they were unnecessary. However, Stan knows they are important, so he wants two checks: (1) each accounts payable clerk (Nancy and Robert) to check the other's work, and (2) the senior accountant (Mary) to check the work of both of the accounts payable clerks. Linda designed some controls that met Stan's expectations and the controls have been in place for three months.

B2: Each Tuesday evening, the City runs checks for the invoices that are due that week. Then, on Wednesday morning, the accounts payable clerks verify the amount of each check with the register and also confirm that all supporting documents are attached. After Mary reviews the registers and documentation, the checks are mailed out to the vendors. Mary reviews Nancy's and Robert's work and notes that all checks and supporting documents are accounted for this week.

C2: Robert and Linda are the only employees who have been with the department long enough to accrue any vacation time. Robert just retumed from a four-day vacation hiking in the Big Bend area. Linda and her husband spent a week at the beach earlier this year. 